\title{
Effect of preharvest and postharvest application of calcium on banana green-life
}

\author{
Philippe TIXIER $^{1 *}$, Christophe BUGAUD ${ }^{2}$, Rémy DUGUET ${ }^{1}$, Frédéric SALMON ${ }^{3}$
}

${ }^{1}$ CIRAD, UPR 26, PRAM, BP 214, 97285 Lamentin Cedex 2, Martinique, FWI, France, tixier@cirad.fr

2 CIRAD, UMR QUALISUD, PRAM, BP 214, 97285 Lamentin Cedex 2, Martinique, FWI, France, bugaud@cirad.fr

${ }^{3}$ CIRAD, UPR 75, Neufchâteau, 97130 Capesterre-Belle-Eau, Guadeloupe, FWI, France, salmon@cirad.fr

* Correspondence and reprints

Fruits, 2010, vol. 65, p. 201-208 (C) 2010 Cirad/EDP Sciences All rights reserved DOI: $10.1051 /$ fruits/2010016 www.fruits-journal.org

RESUMEN ESPAÑOL, p. 208

\section{Effect of preharvest and postharvest application of calcium on banana green-life.}

Abstract - Introduction. Fruit green-life is a major postharvest attribute on which conservation on commodity chains depends. For climacteric fruits such as banana, green-life must be optimized to fit the transport and market requirements. Calcium was assumed to strengthen cellular tissue and increase the green-life of fruits. Materials and methods. In our study, we tested the effect of preharvest and postharvest calcium applications on attributes of banana fruit for two cultivars (Musa spp., AAA group, cv. Cavendish Grande Naine and Flhorban920 cultivar, AAA group). Results and discussion. Extra calcium in fertilization of Flhorban $920 \mathrm{cv}$. did not significantly affect the green-life of fruits (36 days) or the hardness and thickness of the Flhorban920 cv. skin $(63.7 \mathrm{~N}$ and $3.94 \mathrm{~mm}$, respectively). The field calcium applications, by fertilization or spraying, did not alter pulp or peel chemical composition. For postharvest treatments, the green-life of Cavendish and Flhorban920 banana was not significantly altered by the presence or absence of calcium, or by the type of application, 45 and 26 days for the Cavendish and Flhorban920 cultivars, respectively.

Martinica / Musa (bananas) / keeping quality / preharvest treatment / postharvest control / calcium / soaking / spraying

\section{Effet de l'application de calcium avant et après la récolte sur la durée de vie verte de la banane.}

Résumé - Introduction. La durée de vie verte est une caractéristique post-récolte majeure des fruits ; elle définit leur capacité à se conserver au long de la chaîne de distribution. Pour des fruits climactériques comme l'est la banane, la durée de vie verte doit être optimisée afin de satisfaire les exigences de transport et de commercialisation. Le calcium est connu pour renforcer les tissus des plantes ainsi que leur durée de vie verte. Matériel et méthodes. Dans notre étude, nous avons testé l'effet de l'application de calcium avant et après la récolte sur les caractéristiques post-récoltes de bananes de deux cultivars (Grande Naine et Flhorban920, Musa spp., group AAA, Cavendish). Résultats et discussion. L'ajout de calcium dans la fertilisation de la variété Flhorban920 n'a pas au d'effets significatifs sur la durée de vie verte (moyenne de 36 jours), ni sur la dureté et l'épaisseur de la peau des fruits (respectivement $63.7 \mathrm{~N}$ et $3.94 \mathrm{~mm}$ ). L'application de calcium au champ par pulvérisation directe sur les fruits n'a pas modifié la composition chimique de la pulpe et de la peau. Pour les applications de calcium après récoltes (par trempage), la durée de vie verte des fruits de Cavendish et de Flhorban920 n'a été modifiée de manière significative ni par la présence de calcium, ni par le type d'application (durée de vie verte de 45 et 26 jours pour les fruits des variétés Cavendish et Flhorban920, respectivement).

Martinique / Musa (bananes) / aptitude à la conservation / traitement avant récolte / lutte après récolte / calcium / trempage / pulvérisation 


\section{Introduction}

The green-life of climacteric fruits is the postharvest attribute on which their conservation on commodity chains depends, especially when there is a need for transport between the producing and the selling area. The green-life is the time between harvest and the beginning of the climacteric rise. Banana fruits should be transported green and maturation should occur only at selling or in ripening stores. The stage of maturation at which any fruit is harvested greatly influences the green-life [1, 2]. Harvesting at an advanced stage of maturity is unsuitable for fruits intended for long-distance shipment due to their shorter storage-life. The earlier the fruits are harvested, the longer the storage-life, but the smaller the weight. Farmers must thus optimize the green-life to fit the commodity chain requirements and to maximize the yield.

Postharvest techniques to increase greenlife are mainly based on controlled atmospheres or ethylene absorbers. Calcium coating is also known to extend the shelf-life of fruits, e.g. apples [3]. Nevertheless, calcium sprays on peach fruits had no effect on their shelf-life [4]. In postharvest application, calcium is assumed to be an extracellular stimulus that elicits calcium sensors involved in plant defense [5]. Furthermore, calcium was shown to modify pectins and hemicelluloses, which are known to influence the physical properties of fruits [6-9]. For banana, no effect of calcium on fruit shelflife has been shown [10].

To our knowledge, no study has investigated the effect of calcium treatments on the green-life of climacteric fruit in general and banana in particular. Herein, we present the results of preharvest and postharvest applications of calcium on the green-life of two cultivars of banana. We also measured the effect of preharvest calcium applications on peel and pulp postharvest characteristics.

\section{Materials and methods}

\subsection{Banana varieties}

Our study focused on the classic 'Cavendish' cultivar (Musa spp., AAA group, cv. Caven- dish Grande Naine) and on a new triploid hybrid (Flhorban920 cultivar, AAA group). This hybrid is partially resistant to Yellow Sigatoka and Black Leaf Streak Disease [11]; it presents good tolerance to plant parasitic nematodes [12, 13], and has sensory and nutritional characteristics that are different from those of Cavendish banana [14]. Such triploids are issued from conventional breeding techniques [15], including diploid resistant genitors previously doubled with colchicine [16].

The two varieties of banana were grown in Martinique (French West Indies), on a plot located at $14^{\circ} 48^{\prime} 16.0^{\prime \prime} \mathrm{N} ; 61^{\circ} 01^{\prime}$ 58.5" W and $125 \mathrm{~m}$ altitude, on nitisol. The climate in this area is characterized by $2110 \mathrm{~mm}$ of rain annually and a mean temperature of $25.8^{\circ} \mathrm{C}$. Bunches were harvested at a precise physiological stage measured in heat units accumulated since the emergence of the flower, calculated in degree-days (dd). Flhorban920 and Cavendish were harvested at $1200 \mathrm{dd}$ and $1000 \mathrm{dd}$, respectively. The heat units were calculated according to a temperature base equal to $9^{\circ} \mathrm{C}$ for Flhorban920 [17] and $14^{\circ} \mathrm{C}$ for Cavendish [18].

\subsection{Field trial}

For the hybrid Flhorban920, we conducted a field trial to test the effect, on the fruit green-life and fruit peel hardness and thickness, of adding calcium in the fertilization and of spraying calcium in the field directly on the bunch. Treatments included: (1) control with standard fertilization (100 g of complete fertilizer per plant per month; $14 \%$ nitrogen; 7\% phosphorous; $20 \%$ of potash), (2) standard fertilization + calcium added to soil (two times $50 \mathrm{~g}$ of $\mathrm{CaCO}_{3} ; 2$ months and 3 months before harvest; (3) standard fertilization + one liter of a $5 \mathrm{~g} \cdot \mathrm{L}^{-1} \mathrm{CaCO}_{3}$ water solution sprayed directly on the bunch (two times, 2 months and 3 months before harvest). The calcium formulation was Megagreen ${ }^{\circledR}$ from Tribo Technologies ${ }^{\circledR}$, which is an activated form of calcium, including 14\% $\mathrm{CaCO}_{2}, 8 \% \mathrm{SiO}_{2}$ and 3\% MgO. Nine bunches were analyzed per treatment. No difference between treatments was observed in the 
growth of banana plants, i.e., number and weight of fruits and banana pseudo-trunk diameter. The period of measurement was preformed over three weeks in order to limit seasonal variation in mineral composition [19].

\subsection{Pre-packing bath trial}

Clusters of four bananas issued from the 2nd, 3rd and 4th banana hands from the top of the bunch were rinsed with alum sulfate $\left(2 \mathrm{~g} \cdot \mathrm{L}^{-1}\right)$ and dipped in fungicide (bitertanol, $\left.200 \mathrm{mg} \cdot \mathrm{L}^{-1}\right)$ to prevent any postharvest disease that could modify the green-life [20].

We tested the effect of postharvest calcium application on the fruit green-life of Flhorban920 and Cavendish bananas. Five treatments were used: (A) spray with the tested solution then no rinsing, (B) soak for 1 min then rinsing with water, (C) soak for 10 min then rinsing with water, (D) soak for 100 min then rinsing with water, and (E) soak for 100 min with no rinsing. All treatments were done with $0 \%$ and $5 \%$ of a $\mathrm{CaCO}_{3}$ water solution. We used the same calcium formulation (Megagreen ${ }^{\circledR}$ ) as for the field trials. Nine bunches were analyzed per treatment.

\subsection{Postharvest measurements}

The clusters of fruits were packed in separate perforated plastic bags with $20-\mu \mathrm{m}$ holes to prevent desiccation and ethylene contamination. They were stored in ventilated climatic chambers set at $14{ }^{\circ} \mathrm{C}$ until the fruit began to soften, indicating the climacteric crisis. These standardized conditions mimic the transportation by boat of banana in reefer containers from the producer country to the importing country. The green-life was calculated as the time between harvest and the climacteric crisis [21]. The end of green-life, corresponding to the climacteric peak, was defined by the time-point when fruit firmness suddenly decreased (measured manually daily) and when the fruit turned yellow for both cultivars. Peel hardness was determined with a TA-XT2 texture analyzer (Stable Micro Systems, Haslemere, UK) that allows determining the force nec- essary to perforate the peel. The peel thickness was measured after harvest on green fruits, using a caliper rule. Finally, the peel and pulp chemical composition was measured for the different preharvest treatments. We analyzed the $\mathrm{K}, \mathrm{Ca}, \mathrm{Mg}$ and $\mathrm{P}$ content of peel and pulp according to MartinPrével's methods [22].

\subsection{Statistical methods}

To compare preharvest treatments, we performed analyses of variance (ANOVA). Values of green-life were subjected to a twoway analysis of variance that included the effects of the presence of calcium, of the treatments A to E, and interactions between the presence of calcium and treatment. All statistical analyses were performed using the R software [23].

\section{Results and discussion}

\subsection{Effect of calcium added in the field on Flhorban 920 postharvest properties}

Extra calcium used for Flhorban920 cv. fertilization did not significantly affect the green-life of fruits or the skin hardness and thickness (table I). The mean value of the green-life (control + treatment) was $(36 \pm 8)$ days. This green-life is consistent with what we expected, i.e., green-life is sufficient to transport the fruits in conditions of export. We hypothesize that the absence of effect could be due to the quantity of calcium applied, that was perhaps too small. Future studies should test bigger quantities of calcium and more frequent applications. The mean hardness of the Flhorban $920 \mathrm{cv}$. skin (control + treatment) was $(63 \pm 6) \mathrm{N}$, which is higher than the value of $50 \mathrm{~N}$ generally observed for Cavendish cv. [14]. The mean thickness of the Flhorban920 cv. skin (control + treatment $)$ was $(4.0 \pm 0.5) \mathrm{mm}$, which is also higher than what is generally observed for this cultivar [14]. The slight differences observed between our results and those of other authors could be explained by the different growing areas and harvest 


\section{P. Tixier et al.}

Table I.

Measurements of the effect of calcium applied in the field by soil enrichment and spraying, on the peel hardness and thickness, and the green-life of banana hybrid Flhorban920.

\begin{tabular}{|c|c|c|c|c|c|c|c|c|c|}
\hline \multirow[t]{2}{*}{ Parameter } & \multicolumn{3}{|c|}{$\begin{array}{l}\text { Peel hardness } \\
\text { (N) }\end{array}$} & \multicolumn{3}{|c|}{$\begin{array}{l}\text { Peel thickness } \\
(\mathrm{mm})\end{array}$} & \multicolumn{3}{|c|}{$\begin{array}{l}\text { Green-life } \\
\text { (days) }\end{array}$} \\
\hline & Control & $\begin{array}{c}\mathrm{CaO} \text { soil } \\
\text { enrichment }\end{array}$ & $\begin{array}{l}\text { CaO sprayed } \\
\text { on fruits }\end{array}$ & Control & $\begin{array}{l}\mathrm{CaO} \text { soil } \\
\text { enrichment }\end{array}$ & $\begin{array}{c}\mathrm{CaO} \text { sprayed } \\
\text { on fruits }\end{array}$ & Control & $\begin{array}{c}\mathrm{CaO} \text { soil } \\
\text { enrichment }\end{array}$ & $\begin{array}{c}\mathrm{CaO} \text { sprayed } \\
\text { on fruits }\end{array}$ \\
\hline Mean value & 63.64 & 63.74 & 59.00 & 3.90 & 3.98 & 3.74 & 35.27 & 36.33 & 36.40 \\
\hline $\begin{array}{l}\text { Standard } \\
\text { deviation }\end{array}$ & 5.37 & 7.30 & 9.21 & 0.58 & 0.37 & 0.61 & 5.78 & 9.24 & 2.32 \\
\hline $\mathrm{T}$ & - & -0.04 & 1.07 & - & -0.42 & 0.51 & - & -0.66 & -1.08 \\
\hline$p$-value & - & 0.968 & 0.344 & - & 0.676 & 0.626 & - & 0.514 & 0.285 \\
\hline
\end{tabular}

\section{Table II.}

Measurements of the effect of calcium applied in the field by soil enrichment and spraying on the peel and pulp chemical composition ( $\mathrm{K}, \mathrm{Ca}, \mathrm{Mg}$ and $\mathrm{P}$ expressed in \%) for the Flhorban920 banana.

\begin{tabular}{|c|c|c|c|c|c|c|c|c|c|c|c|c|}
\hline \multirow[t]{2}{*}{ Parameter } & \multicolumn{3}{|c|}{$\mathrm{K}$} & \multicolumn{3}{|c|}{$\mathrm{Ca}$} & \multicolumn{3}{|c|}{$\mathrm{Mg}$} & \multicolumn{3}{|c|}{$\mathrm{P}$} \\
\hline & Control & $\begin{array}{l}\mathrm{CaO} \text { soil } \\
\text { enrichment }\end{array}$ & $\begin{array}{c}\mathrm{CaO} \\
\text { sprayed } \\
\text { on fruits }\end{array}$ & Control & $\begin{array}{l}\mathrm{CaO} \text { soil } \\
\text { enrichment }\end{array}$ & $\begin{array}{c}\mathrm{CaO} \\
\text { sprayed } \\
\text { on fruits }\end{array}$ & Control & $\begin{array}{l}\mathrm{CaO} \text { soil } \\
\text { enrichment }\end{array}$ & $\begin{array}{c}\mathrm{CaO} \\
\text { sprayed } \\
\text { on fruits }\end{array}$ & Control & $\begin{array}{c}\mathrm{CaO} \text { soil } \\
\text { enrichment }\end{array}$ & $\begin{array}{c}\mathrm{CaO} \\
\text { sprayed } \\
\text { on fruits }\end{array}$ \\
\hline \multicolumn{13}{|l|}{ Pulp } \\
\hline $\begin{array}{l}\text { Mean } \\
\text { value }\end{array}$ & 2.644 & 2.536 & 2.503 & 0.096 & 0.084 & 0.107 & 0.236 & 0.228 & 0.232 & 0.220 & 0.220 & 0.214 \\
\hline SD & 0.080 & 0.085 & 0.110 & 0.004 & 0.009 & 0.011 & 0.003 & 0.005 & 0.025 & 0.011 & 0.013 & 0.028 \\
\hline$T$ & - & 1.017 & 1.033 & - & 1.599 & 1.966 & - & 2.085 & 0.249 & - & 0.001 & 0.104 \\
\hline$p$-value & - & 0.337 & 0.349 & - & 0.235 & 0.210 & - & 0.179 & 0.636 & - & 0.975 & 0.758 \\
\hline \multicolumn{13}{|l|}{ Peel } \\
\hline $\begin{array}{l}\text { Mean } \\
\text { value }\end{array}$ & 7.154 & 7.910 & 9.989 & 0.633 & 0.616 & 0.610 & 0.235 & 0.227 & 0.264 & 0.238 & 0.255 & 0.297 \\
\hline SD & 0.937 & 1.117 & 0.281 & 0.140 & 0.098 & 0.027 & 0.031 & 0.033 & 0.041 & 0.023 & 0.031 & 0.046 \\
\hline $\mathrm{T}$ & - & 1.146 & 0.302 & - & $4,00 \mathrm{E}-04$ & 0.01 & - & 0.005 & 0.302 & - & 0.539 & 2.016 \\
\hline$p$-value & - & 0.312 & 0.603 & - & 0.984 & 0.924 & - & 0.944 & 0.603 & - & 0.481 & 0.205 \\
\hline
\end{tabular}

$p$-value of T test with $\alpha=0.05$.

season, known to alter peel properties. Our results differ from those on peach, for which calcium chloride application to trees increased peel thickness [24] or on olives, for which calcium increased firmness [25].

Chemical analyses showed that field calcium applications, by fertilization or spraying, did not alter pulp or peel chemical composition (table II). These chemical compositions were not different from those reported by other authors [21]. The compo- sition of banana varies with the variety [26] and we expected this composition to be modified by calcium application. Yet improving fruit calcium concentrations is often difficult to achieve. Attempts to increase calcium fruit levels have not always been successful, and some results are contradictory [27, 28]. Future studies should test higher calcium doses and longer applications. In contrast with other fruits with thinner peels and for which calcium can be 


\section{Table III.}

Results of the statistical analysis of the linear model: green-life explained by the effects of the presence of calcium, treatment ${ }^{1}$, and interactions between the presence of calcium and treatment for Cavendish and Flhorban920 cvs.

\begin{tabular}{|c|c|c|c|c|c|}
\hline Source of variation & Degrees of freedom & $\begin{array}{c}\text { Sum } \\
\text { of squares }\end{array}$ & Mean squares & $F$ values & $p$-values \\
\hline \multicolumn{6}{|l|}{ Cavendish } \\
\hline Calcium & 1 & 64.0 & 64.0 & 0.4366 & 0.5107 \\
\hline Treatment & 4 & 237.7 & 59.4 & 0.4056 & 0.8041 \\
\hline [Calcium $\times$ treatment] & 4 & 456.0 & 114.0 & 0.7780 & 0.5429 \\
\hline Residuals & - & 77.0 & 11281.3 & 146.5 & - \\
\hline \multicolumn{6}{|l|}{ Flhorban920 } \\
\hline Calcium & 1 & 47.0 & 47.0 & 0.5326 & 0.4677 \\
\hline Treatment & 4 & 347.7 & 86.9 & 0.9848 & 0.4210 \\
\hline [Calcium $\times$ treatment] & 4 & 121.6 & 30.4 & 0.3445 & 0.8471 \\
\hline Residuals & 77 & 6797.4 & 88.3 & - & - \\
\hline
\end{tabular}

increased by preharvest spray [4], banana has a thick peel with a thick cuticle and appears more impermeable to external applications.

\subsection{Effect of calcium added in pre-packing bath on Cavendish and Flhorban 920 green-life}

The banana green-life was not significantly altered by the presence or absence of calcium, or by the A to E treatments applied (table III). Statistically, there was no interaction between the presence of calcium and the treatments. We observed the same results for the Cavendish and for the Flhorban 920 cvs. Mean green-life was $45 \mathrm{~d}$ for Cavendish cv. (figure 1), which is consistent with Bugaud et al. [21]. For the Flhorban $920 \mathrm{cv}$., mean green-life was $26 \mathrm{~d}$ (figure 2), which is lower than for the Cavendish $\mathrm{cv}$. and in line with results of Bugaud et al. [14]. In all treatments, the standard deviation had the same magnitude: between (7 and 17) d for Cavendish, and between ( 7 and 11) d Flhorban920 cvs. Our results are consistent with those of other authors on the shelf-life of banana dipped for $20 \mathrm{~min}$ in a $\mathrm{CaCl}_{2}$ solution at $4 \%$ [10]. One hypothesis to explain this absence of effect is that the peel of banana is thick and relatively hydrophobic. These peel properties are not favorable to the penetration of the calcium solution inside the fruits and thus having an effect on postharvest characteristics.

Our preharvest and postharvest results did not show any effect of calcium on the green-life of banana or on any postharvest characteristics. Another option could be to synergize calcium with other products, e.g., calcium and additional factors such as palm kernel or coconut oil, which may lead to better maintenance of the water content of banana peel [29]. However, those authors used a 24-hour dipping, which is not compatible with the conditions of packing. In other crops, similarly, no effects were observed, especially on fruit hardness, for instance in the case of green bell peppers (Capsicum annuum), for which immersion in $\mathrm{CaCl}_{2}$-solution alone did not improve firmness [30]. Although the form of calcium we used was an activated form, other forms such as $\mathrm{CaCl}_{2}$-solutions should be tested on 


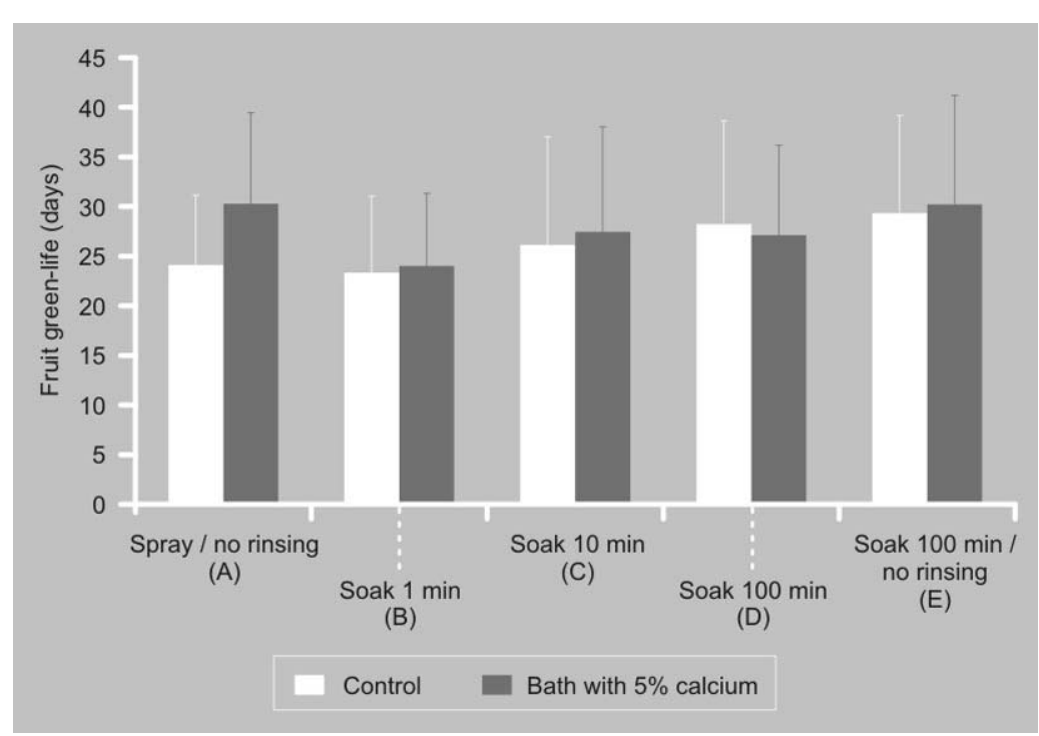

Figure 1.

Green-life of Flhorban920

banana for different times in a pre-packing bath containing $5 \%$ of calcium and control (all results are not significant).

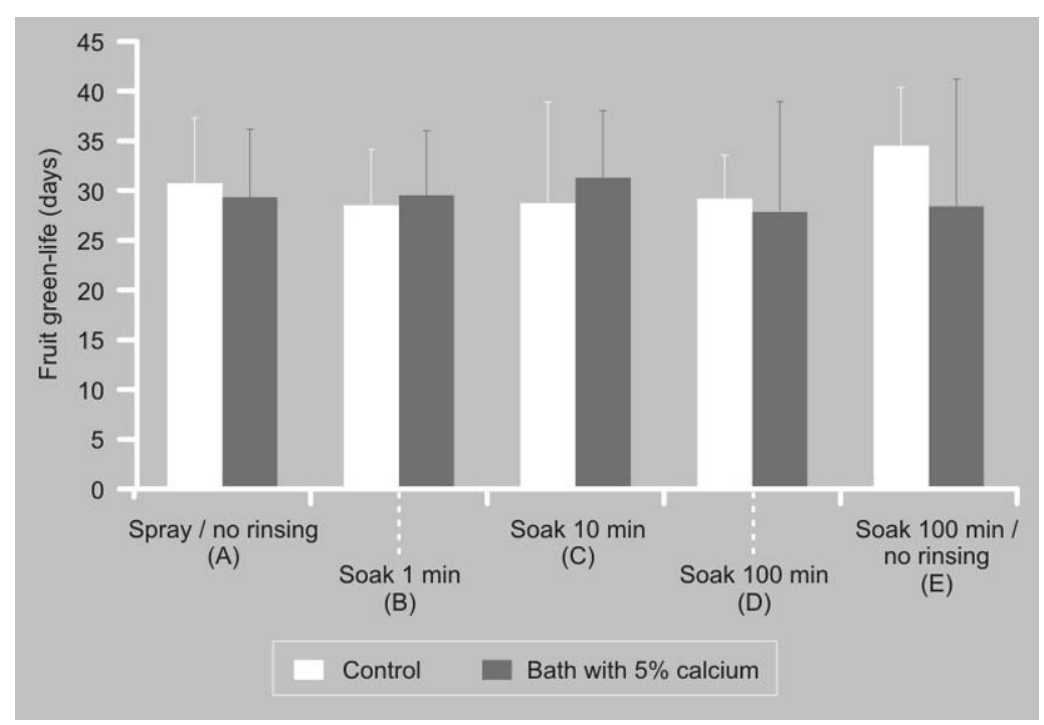

Figure 2.

Green-life of Cavendish banana for different times in a pre-packing bath containing $5 \%$ of calcium and control (all results are not significant). the green-life of banana. It has been reported, however, that this did not increase shelf-life [10]. To increase banana green-life, research should focus on indirect effects such as the use of ethylene antagonists such as 1-methylcyclopropene (1-MCP), which can extend the marketable shelf-life of banana [31, 32], rather than target a direct chemical effect either at the preharvest or postharvest stage. Another prospect for increasing the green-life of banana might be storing ethylene-pretreated banana clusters under vacuum for (24 to 48) h [33].

\section{Acknowledgments}

We thank Marie-Odette Daribo, Irene Salas and Olivier Birba for technical assistance. We also thank Gary Burkhart for the language editing.

\section{References}

[1] Bugaud C., Lassoudière A., Variability in the green shelf life of bananas in real conditions of production, Fruits 60 (2005) 227-236.

[2] Tixier P., Salmon F., Bugaud C., Green-life of pink banana (Musa spp., cv. Figue Rose Naine): determination of the optimum harvesting date, J. Hortic. Sci. Biotech. (2010) in press.

[3] Olivas G.I., Mattinson D.S., Barbosa-Canovas G.V., Alginate coatings for preservation of minimally processed 'Gala' apples, Postharvest Biol. Technol. 45 (2007) 89-96.

[4] Manganaris G.A., Vasilakakis M., Mignani I., Diamantidis G., Tzavella-Klonari K., The effect of preharvest calcium sprays on quality attributes, physicochemical aspects of cell wall components and susceptibility to brown rot of peach fruits (Prunus persica L. cv. Andross), Sci. Hortic.-Amsterdam 107 (2005) 43-50.

[5] Yang T., Poovaiah B.W., Calcium/calmodulin-mediated signal network in plants, Trends Plant Sci. 8 (2003) 505-512.

[6] Billy L., Mehinagic E., Royer G., Renard C.M.G.C., Arvisenet G., Prost C., Jourjon F., Relationship between texture and pectin composition of two apple cultivars during storage, Postharvest Biol. Technol. 47 (2008) 315-324. 
[7] De Roeck A., Sila D.N., Duvetter T., Van Loey A., Hendrickx M., Effect of high pressure/high temperature processing on cell wall pectic substances in relation to firmness of carrot tissue, Food Chem. 107 (2008) 1225-1235.

[8] Duan X., Cheng G., Yang E., Yi C., Ruenroengklin N., Lu W., Luo Y., Jiang Y., Modification of pectin polysaccharides during ripening of postharvest banana fruit, Food Chem. 111 (2008) 144-149.

[9] Zhang L., Chen F., An H., Yang H., Sun X., Guo X., Li L., Physicochemical properties, firmness, and nanostructures of sodium carbonate-soluble pectin of 2 Chinese cherry cultivars at two ripening stages, J. Food Sci. 73 (2008)

[10] Perera A.N., Karunaratne A.M., Postharvest calcium chloride treatments do not help to increase shelf-life of bananas, Fruits 57 (2002) 87-94.

[11] Abadie C., Chilin-Charles Y., Huat J., Salmon F., Pignolet L., Carlier J., Lescot T., Côte F., Jenny C., New approaches to select durable resistant varieties of bananas against Mycosphaerella leaf spot diseases, in: Jones D., Van den Bergh I. (Eds.), ProMusa Symp.: Recent advances in banana crop protection for sustainable production and improved livelihoods, ISHS, White River, S. Afr., 2007.

[12] QuénéhervéP., ValetteC., Topart P., Tezenas Du Montcel H., Salmon F., Nematode resistance in bananas: Screening results on some wild and cultivated accessions of Musa spp., Euphytica 165 (2009) 123-136.

[13] Tixier P., Malézieux E., Dorel M., Wery J., SIMBA, a model for designing sustainable banana-based cropping systems, Agric. Syst. 97 (2008) 139-150.

[14] Bugaud C., Alter P., Daribo M.O., Brillouet J.M., Comparison of the physico-chemical characteristics of a new triploid banana hybrid, Flhorban 920, and the Cavendish variety, J. Sci. Food Agric. 89 (2009) 407-413.

[15] Jenny C., Tomekpe K., Bakry F., Escalant J.-V., Conventional breeding of bananas, in: Jacome L., Lepoivre P., Marin D., Ortiz R., Romero R., Escalant J.-V. (Eds.), Int. workshop on Mycosphaerella leaf spot diseases of bananas, INIBAP, San José, Costa-Rica, 2003, pp. 199-208.

[16] Bakry F., Paulo De La Reberdiere N., Pichot S., Jenny C., In liquid medium colchicine treatment induces non chimerical doubleddiploids in a wide range of mono- and inter- specific diploid banana clones, Fruits 62 (2007) 3-12.

[17] Salmon F., Bugaud C., Chillet M., Dorel M., Risède J.-M., Jenny C., Côte F., Development of a new promising banana hybrid: "Flhorban 920", 41st Annu. Meet. Carrib. Food Crop Soc., Caribb. Food Crops Soc., Gosier, Guadeloupe, 2005.

[18] Ganry J., Meyer J.-P., Recherche d'une loi d'action de la température sur la croissance des fruits du bananier, Fruits 30 (1975) 375392.

[19] Bugaud C., Daribo M.O., Beaut M.P., Telle N., Dubois C., Relative importance of location and period of banana bunch growth in carbohydrate content and mineral composition of fruit, Fruits 64 (2009) 63-74.

[20] Chillet M., Abadie C., Hubert O., ChilinCharles Y., de Lapeyre de Bellaire L., Sigatoka disease reduces the greenlife of bananas, Crop Prot. 28 (2009) 41-45.

[21] Bugaud C., Chillet M., Beaute M.P., Dubois C., Physicochemical analysis of mountain bananas from the French West Indies, Sci. Hortic-Amsterdam 108 (2006) 167-172.

[22] Anon., L'analyse végétale dans le contrôle de l'alimentation des plantes tempérées et tropicales, Martin-Prével M., Gagnard J., Gautier P. (Eds.), Tech. Doc., Lavoisier, Paris, France, 1984.

[23] Anon., R Development Core Team, R: A Language and Environment for Statistical Computing, R.F.F.S. Computing (Ed.), Vienna, Austria, 2008.

[24] ElmerP.A.G., Spiers T.M., Wood P.N., Effects of pre-harvest foliar calcium sprays on fruit calcium levels and brown rot of peaches, Crop Prot. 26 (2007) 11-18.

[25] Tsantili E., Christopoulos M.V., Pontikis C.A., Kaltsikes P., Kallianou C., Komaitis M., Texture and other quality attributes in olives and leaf characteristics after preharvest calcium chloride sprays, HortScience 43 (2008) 1852-1856.

[26] Happi Emaga T., Andrianaivo R.H., Wathelet B., Tchango J.T., Paquot M., Effects of the stage of maturation and varieties on the chemical composition of banana and plantain peels, Food Chem. 103 (2007) 590-600.

[27] Kadir S.A., Fruit quality at harvest of "Jonathan" apple treated with foliarly-applied calcium chloride, J. Plant Nutr. 27 (2004) 1991-2006. 
[28] Roy S., Conway W.S., Watada A.E., Sams C.E., Erbe E.F., Wergin W.P., Changes in the ultrastructure of the epicuticular wax and postharvest calcium uptake in apples, HortScience 34 (1999) 121-124.

[29] Aghofack-Nguemezi J., Dassie B., Effects of salts and edible oils on calcium and water contents in ripening banana fruits, J. Plant Sci. 2 (2007) 302-309.

[30] Castro S.M., Loey A.V., Saraiva J.A., Smout C., Hendrickx M., Effect of temperature, pressure and calcium soaking pre-treatments and pressure shift freezing on the texture and texture evolution of frozen green bell peppers (Capsicum annuum), Eur. Food Res. Technol. 226 (2007) 33-43.
[31] Huber D.J., Suppression of ethylene responses through application of 1-methylcyclopropene: A powerful tool for elucidating ripening and senescence mechanisms in climacteric and nonclimacteric fruits and vegetables, HortScience 43 (2008) 106-111.

[32] Stanley D., Huber D., Large-scale application of 1-methylcyclopropene results in extended marketable shelf life and persistence of the full-ripe condition of commercially handled banana fruit, HortScience 39 (2004) 816-817.

[33] Pesis E., Arie R.B., Feygenberg O., Villamizar F., Ripening of ethylene-pretreated bananas is retarded using modified atmosphere and vacuum packaging, HortScience 40 (2005) 726-731.

\section{Efecto de la aplicación de calcio antes y después de la cosecha, en la duración de vida verde de la banana.}

Resumen - Introducción. La duración de vida verde de los frutos es una característica fundamental post-cosecha, ya que define la capacidad de los frutos de conservarse a lo largo de la cadena de distribución. Para frutos climatéricos, como es el caso de la banana, la duración de vida verde debe optimizarse con el fin de satisfacer las exigencias del transporte y de la comercialización. Se sabe del calcio que refuerza los tejidos de las plantas y la duración de vida verde. Material y métodos. En nuestro estudio, sometimos a testeo el efecto que tiene la aplicación de calcio, antes y después de la cosecha, en las características post-cosecha de las bananas de dos cultivares (Grande Naine y Flhorban920, Musa spp., AAA group, Cavendish). Resultados y discusión. El aporte de calcio en la fertilización de la variedad Flhorban920 no tuvo efectos significativos en la duración de vida verde (una media de 36 días), ni en la dureza y espesor de la cáscara de los frutos (respectivamente $63.7 \mathrm{~N} \mathrm{y}$ $3.94 \mathrm{~mm}$ ). La aplicación de calcio sobre el terreno mediante pulverización directa sobre los frutos no modificó la composición química de la pulpa ni de la cáscara. Para las aplicaciones de calcio después de las cosechas (mediante inmersión), la duración de vida verde de los frutos de Cavendish y de Flhorban920 no se modificó de manera significativa por la presencia de calcio ni por el tipo de aplicación (duración de vida verde de 45 y de 26 días para los frutos de las variedades Cavendish y Flhorban920, respectivamente).

Martinique / Musa (bananos) / aptitud para la conservación / tratamiento precosecha / control de plagas (postcosecha)/ calcio / remojo / pulverización 